\title{
Bladder Distention due to Electrocautery Knife Use in Spine Surgery: The First Experimental Study
}

\author{
Omurga Cerrahisinde Elektrokoter Bıçağı kullanımına bağı Idrar Kesesi Distansiyonu: \\ ilk Deneysel Çalıșma
}

\author{
Mehmet Kursat Karadag', Ahmet Yardim², Aslihan Alpaslan Duman³, Mehmet Dumlu Aydin' \\ ${ }^{1}$ Department of Neurosurgery, Medical Faculty of Ataturk University, Erzurum,Turkey; ${ }^{2}$ Department of Neurosurgery, Medical Faculty of \\ Aksaray University, Aksaray, Turkey; ${ }^{3}$ Department of Pathology, Medical Faculty of Giresun University, Giresun, Turkey
}

\begin{abstract}
Aim: In our study, we aimed to examine the mechanism of ACA/ sacral parasympathetic network injury and its effects on the bladder, which have not been included in the literature before, due to the use of electrocautery knife in spinal surgery.
\end{abstract}

Material and Method: Twenty hybrid rabbits were used in our study. Five of the animals were evaluated as the control (control group). Surgery was performed on 6 of them using bipolar electrocautery knife (BEC group) and 9 using monopolar electrocautery knife (MEC group). Th11-L2 spinal laminectomy was performed on animals during surgery. Animals were sacrificed after bladder tomography was taken one week later. After sacrification, the bladder and Onuf nucleus/S4 spinal ganglia were taken for histopathological examination. Bladder volume values and 54 ganglion density values were compared statistically using the Man Whitney-U test.

Results: Bladder volume values were found to be $48 \pm 5 \mathrm{~cm}^{3}$ in the control group. It was found to be $52 \pm 6 \mathrm{~cm}^{3}$ in the BEC group and $75 \pm 9 \mathrm{~cm}^{3}$ in the MEC group. S4 dorsal root ganglion densities were $8 \pm 3 / \mathrm{mm}^{3}$ in the control group and $143 \pm 23 / \mathrm{mm}^{3}$ in the BEC group, and It was found to be $643 \pm 75 / \mathrm{mm}^{3}$ in the MEC group. The results were statistically significant.

Conclusion: As a result of the findings we obtained in our study, we recommend that the high-voltage MEC/BEC electrocautery blade should not be used in spine surgery unless it is necessary due to its dangerous effects on AKA, sacral parasympathetic network, and consequently, the urogenital system.

Key words: spinal surgery; electrocautery knife; bladder

\section{ÖZET}

Amaç: Çalıșmamızda literatürde daha önce yer almayan, omurga cerrahisinde elektrokoter bıçağı kullanımına bağlı, AKA/sakral parasempatik ağ hasarı olușma mekanizması ve mesane üzerindeki etkilerini incelemeyi amaçladık.

Materyal ve Metot: Çalıșmamızda 20 hibrit tavșan kullanıldı. Hayvanlardan beși kontrol (Kontrol grubu) olarak değerlendirildi. Altı tanesine bipolar elektrokoter kullanılarak (BEC grubu), dokuz tanesine monopolar elektrokoter kullanılarak (MEC grubu) cerrahi müdahale yapıldı. Cerrahi müdahalede hayvanlara Th11-L2 spinal laminektomi yapıldı. Bir hafta sonra hayvanların mesane tomografileri çekildikten sonra hayvanlar sakrifiye edildi. Sakrifikasyon sonrası hayvanların mesanesi ve Onuf nukleus/S4 spinal gangliyonları histopatolojik inceleme amaçlı alındı. Mesane hacim değerleri ve S4 gangliyon dansite değerleri Man Whitney-U testi kullanılarak istatistiksel olarak karșılaștırıldı.

Bulgular: Mesane hacim değerleri kontrol grubunda $48 \pm 5 \mathrm{~cm}^{3}$ olarak saptandl; BEC grubunda $52 \pm 6 \mathrm{~cm}^{3}$ ve MEC grubunda $75 \pm 9$ $\mathrm{cm}^{3}$ olarak bulundu. S4 dorsal root gangliyon dansiteleri kontrol grubunda $8 \pm 3 / \mathrm{mm}^{3}$, BEC grubunda $143 \pm 23 / \mathrm{mm}^{3}$; MEC grubunda $643 \pm 75 / \mathrm{mm}^{3}$ olarak bulundu. Sonuçlar istatistiksel olarak anlamlı olarak saptandl.

Sonuç: Çalıșmamızda elde ettiğimiz bulgular sonucunda yüksek voltajlı MEC/BEC elektrokoter bıçă̆ını, AKA, sakral parasempatik ağ ve sonuç olarak ürogenital sistem üzerine olan tehlikeli etkileri nedeniyle zorunlu olmadıkça omurga cerrahisinde kullanılmamasını önermekteyiz.

Anahtar kelimeler: spinal cerrahi; elektrokoter bıçak; mesane

IIetișim/Contact: Ahmet Yardım, Department of Neurosurgery, Medical Faculty of Aksaray University, Aksaray, Turkey • Tel: 05052468665 • E-mail:drahmetyardim01@gmail.com • Geliș/Received:27.12.2020 • Kabul/Accepted:07.02.2021

ORCID: Mehmet Kürşat Karadăg, 0000-0001-9123-0597 • Abmet Yardim, 0000-0003-1134-6050 • Aslihan Duman, 0000-0003-0532-3629 • Mehmet Dumlu Aydin, 0000-0002-0383-9739 


\section{Introduction}

The sacral parasympathetic network provides parasympathetic innervation of the urinary system. The sacral parasympathetic bladder motoneurons are located in the Onuf's nucleus in the sacral spinal cord, which Onufrowitz first described in $1899^{1}$. Lower spinal arterial circulation is provided Adamkiewicz artery (AKA) described in 1882 by Adamkiewicz ${ }^{2}$. As a result, AKA provides the circulation of the sacral parasympathetic network.

Vasospasm may develop after spinal subarachnoid hemorrhage ( $\mathrm{SAH})$ in $\mathrm{AKA}^{3}$. AKA vasospasm causes degeneration in the onuf's nucleus/pudendal ganglia due to circulatory failure, and therefore, urinary retention may occur ${ }^{4}$. There may also be intestinal involvement due to AKA vasospasm ${ }^{5}$. As can be understood from these studies, ACA, which provides arterial circulation to the onuf nucleus and dorsal root ganglia (DRG), is very important for abdominopelvic organ functions.

Electrical devices are used for tissue cutting or coagulation in surgeries, and they can be hazardous for live tissues. The mechanism of electrical injury can be explained by thermal damage, vascular impairment, and histological or electrophysiological changes in peripheral nerves or direct electromechanical trauma ${ }^{6}$. With the application of electrocautery, ACA can be affected as circulatory disorders and thrombus development in the radicular arteries ${ }^{7}$. Monopolar (MEC) or bipolar electrocautery knife (BEC) used in spine surgery are examples of commonly used electrical devices. Although MEC and BEC are used frequently, they can cause serious tissue damage like other electrical surgical instruments.

We aimed to show that high voltage BEC/MEC application affects ACA and consequently causes bladder pathology due to neural dysfunction in our study.

\section{Materials and Methods}

Twenty male hybrid rabbits (2 years old and weighing $3.5-0.4 \mathrm{Kg}$ ) were used in our study. Experiments were done according to the approval of the ethical committee of Ataturk University. Five of the animals were allocated for the control group. The remaining animals were anesthetized by general anesthesia $(25 \mathrm{mg} / \mathrm{kg}$ ketamine hydrochloride, $15 \mathrm{mg} / \mathrm{kg}$ lidocaine hydrochloride, and $1 \mathrm{mg} / \mathrm{kg}$ acepromasine). After the required surgical cleaning of the operation site, Th11-L2 laminectomy was applied, and facets were denervated. MEC was used in 8 animals (MEC group) and $\mathrm{BEC}$ in 7 animals during the surgical intervention. MEC and BEC were performed with an electrocaugulator of $220 \mathrm{~V}-50 \mathrm{~Hz}$. Fascia and skin sutured with 3-0 cotton sutures. Animals have followed their cages for seven days postoperatively without antibiotic/analgesic treatment. All animals were taken multislice CT to estimate urinary bladder volumes, and then all animals were sacrificed. S4 spinal ganglia and bladders were removed for histopathological examination. The S4 ganglia specimens and neurovascular bundles of bladders were embedded in paraffin blocks, and sections were stained with hematoxylin \&eosin, tunnel, and aldehyde fuchsine. To estimate urinary bladder volume and Physical dissector method were estimated described by Yolas $\mathrm{C}$ et al. ${ }^{4}$. For neurodegeneration criteria, peri-cytoplasmic halo formation, cytoplasmic condensation, nuclear shrinking, and cellular angulations were accepted. To estimate Adamkiewicz artery degeneration, endothelial swelling, shrinkage, desquamation, and thrombus formation were taken as deformation criteria described by Aydin MD et al.7. The bladder is considered an ellipsoid shape, and its volume is estimated as same as the sphere's volume formula by averaging the $\mathrm{x}, \mathrm{y}, \mathrm{z}$ radii using spherical transformation methods. Statistical analysis between S4 ganglia degenerated neuron density, and bladder volume values were compared with the nonparametric Mann Whitney Test in SPSS 11.0 for Windows.

\section{Results}

The bladder tomography image, the macroscopic bladder view, and how we calculate the bladder volume are clearly shown in Fig. 1. Bladder volume values were detected as $48 \pm 5 \mathrm{~cm}^{3}$ in normal, $52 \pm 6 \mathrm{~cm}^{3}$ in BEC, and $75 \pm 9 \mathrm{~cm}^{3}$ in MEC groups. Degenerated neuron density of $S 4$ dorsal root ganglion (DRG) was $8 \pm 3$ in control, $143 \pm 23 / \mathrm{mm}^{3}$ in BEC, $643 \pm 75 / \mathrm{mm}^{3}$ in the MEC group. $\mathrm{P}<0.005$ between control/BEC; $\mathrm{p}<0.0005$ between BEC/MEC and $\mathrm{p}<0.00001$ between control/ MEC (Table 1). Our results were found to be statistically significant.

Histopathologically, we detected adhesions and fibrotic scar in the peridural space at the operation area. While endothelial and muscle cell degeneration was seen in AKA animals using electrocautery, mainly 


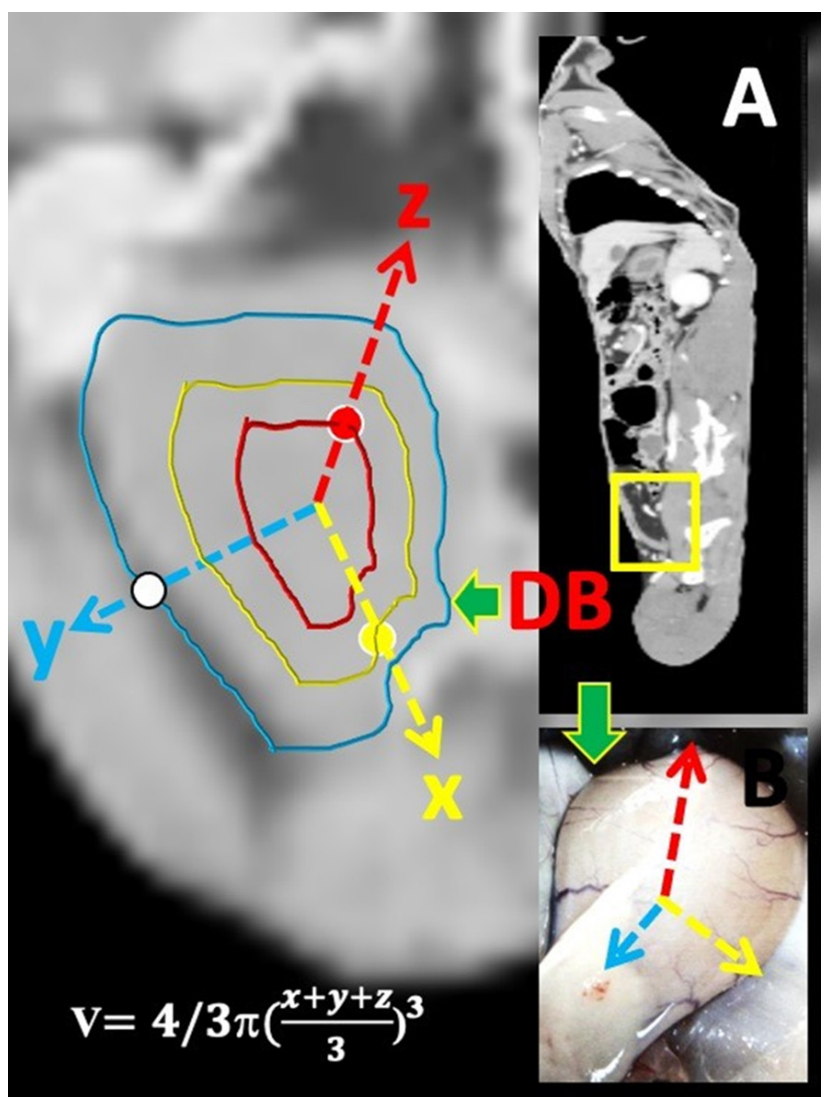

Figure 1. The dilated bladder (DB) tomography image (A), the macroscopic bladder view (B), and the way we calculate the bladder volume (Base).

Table 1. Numerical bladder volume/ $\mathrm{cm}^{3}$ and degenerated neuron density of $D R G / \mathrm{mm}^{3}$

\begin{tabular}{lccc}
\hline & Control Group & BEC Group & MEC Group \\
\hline Bladder volume $/ \mathrm{cm}^{3}$ & $48 \pm 5$ & $52 \pm 6$ & $75 \pm 9$ \\
$\begin{array}{l}\text { Degenerated neuron } \\
\text { density of } \mathrm{DRG} / \mathrm{mm}^{3}\end{array}$ & $8 \pm 3$ & $143 \pm 23$ & $643 \pm 75$ \\
\hline
\end{tabular}

MEC group: $P<0.005$ between control/BEC, $p<0.0005$ between $B E C / M E C$, and $p<0.00001$ between control/MEC.

in the MEC group, no effect was observed in the control group (Fig. 2). Especially in animals in the BEC group, apoptosis and degeneration were observed in neurons in DRG (Fig. 3). Likewise, while no involvement was found in the control group, thrombosis in the bladder arteries and degenerated/demyelinated pudendal nerve axons were evaluated more in the MEC group than in the BEC group histopathologically (Fig. 4).

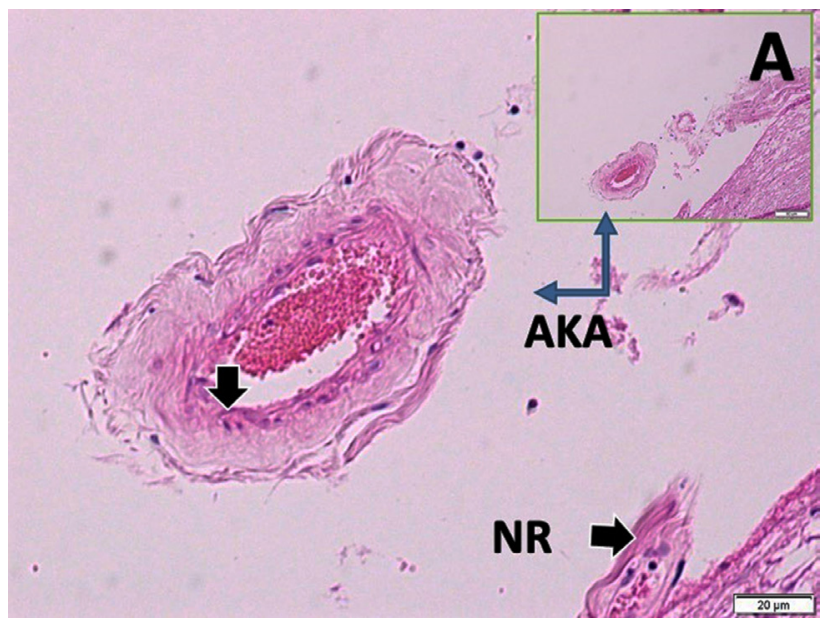

Figure 2. Histopathological appearances of AKA (LM, H\&E, X4/A) and magnified form with degenerated endothelial and muscle cells, nerve root (NR) (LM, H\&E, x40/Base) are seen.

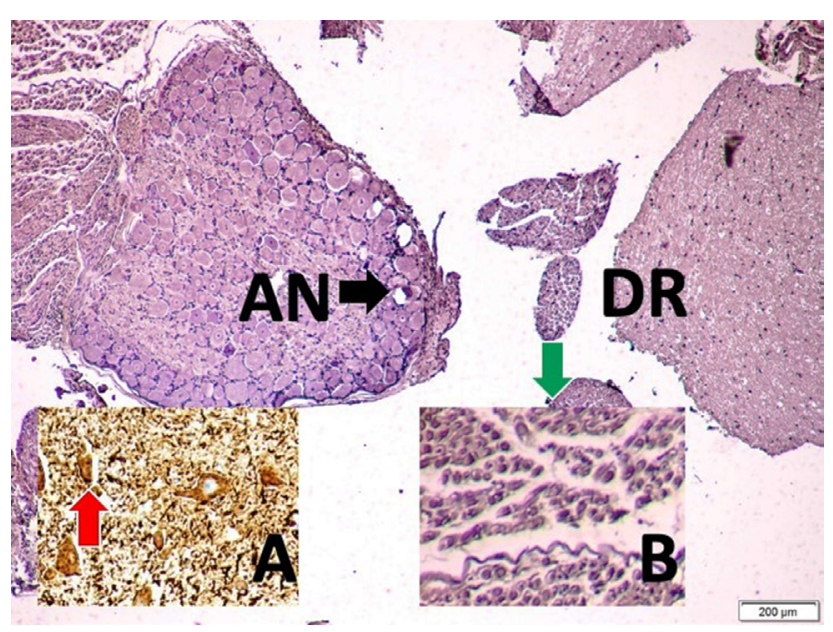

Figure 3. Histopathological appearance of $L 4$ dorsal root ganglion (DR), apoptotic neuron (AN) (LM, H\&E, x10/Base); degenerated or loosened axons (LM, Tunel, $x 10 / A)$ and apoptotic neurons of $L 4$ roots are seen in a MEC applied animal (LM, Tunel, $x 10 / B)$.

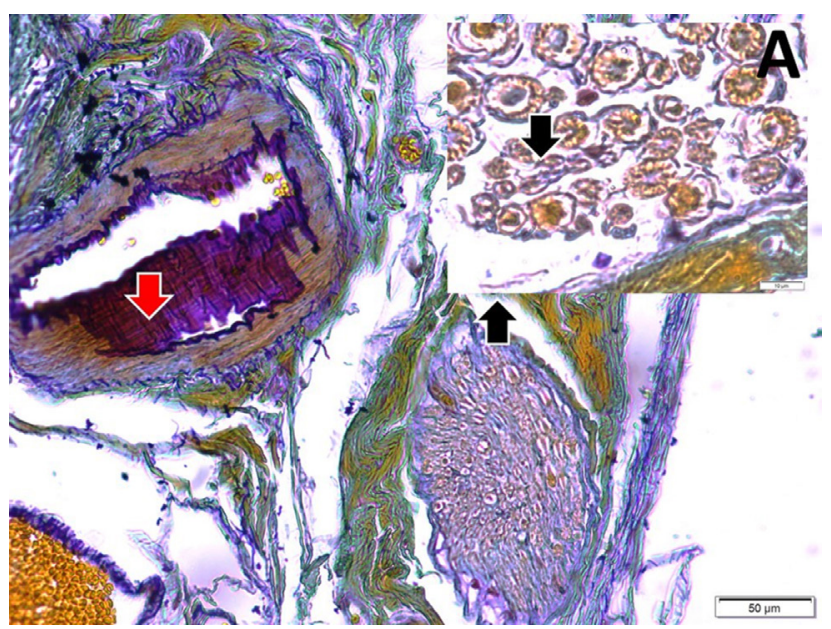

Figure 4. Histopathological appearances of urinary bladder supplying thrombosed arteries (red arrow) (LM, VonGiezon, x20/Base) and degenerated/demyelinated pudendal nerve axons (black arrow) (LM, VonGiezon, x20/A) are seen. 


\section{Discussion}

Electrocautery knives are widely used in spine surgery as MEC or BEC form for soft tissue dissection and thermocoagulation; however, electrical currents have detrimental effects on neural ${ }^{8}$ and vascular tissues ${ }^{9}$.

In Bladder Innervation, the sacral parasympathetic bladder motoneurons are located in the Onuf's nucleus in the sacral spinal cord, and AKA provides the arterial circulation of these neurons. Distal extensions of the dorsal root ganglia travel with the pelvic and hypogastric nerves and through the pudendal nerves that enter the urethra ${ }^{10}$ and the bladder to the bladder for filling and emptying. Afferent urinary bladder fibers are located in a suburothelial plexus, bladder neck, and the trigone six and function as stretch receptors stimulator to start micrution reflex ${ }^{11}$. Sacral parasympathetic stimulate detrusor smooth muscles for bladder contraction to start micturition ${ }^{12}$. It is seen that these functions will be affected with onuf nucleus damage due to the effect of ACA.

Although it was discovered nearly a century ago, we think the importance of the onuf nucleus is not sufficiently understood. Serious studies will be needed to realize the indispensable importance of the Adamkiewicz arterial network, which provides the basic blood support of the neurovascular network, especially the Onuf nucleus complex and the dorsal root ganglia of this region.

Unexplained urogenital complications can occur even after the safest spine surgery. We think that our study sheds light on urogenital complications whose cause cannot be understood after spine surgery. This situation has not been included in the literature before. It further increases the importance of our study results.

We recommend that BEC and MEC not be used during spinal surgery because of their harmful effects unless necessary. In cases where it is needed, it would be more appropriate to choose bec instead of mec, as it has a less harmful impact.

\section{References}

1. Onuf (Onufrowicz) B. Note the arrangement and function of the cell groups in the sacral region of the spinal cord. J Nerv Ment Dis 1899;26:498-504.

2. Mawad ME, Rivera V, Crawford S, Ramirez A, Breitbach W. Spinal cord ischemia after resection of thoracoabdominal aortic aneurysms: MR findings in 24 patients. AJR Am J Roentgenol 155:1303-7, 1990.

3. Turkmenoglu ON, Kanat A, Yolas C, Aydin MD, Ezirmik N, Gundogdu C. First report of important causal relationship between the Adamkiewicz artery vasospasm and dorsal root ganglion cell degeneration in spinal subarachnoid hemorrhage: An experimental study using a rabbit model. Asian J Neurosurg 12:22-7, 2017.

4. Yolas C, Kanat A, Aydin MD, et al. The Important Liaison Between Onuf Nucleus-Pudendal Nerve Ganglia Complex Degeneration and Urinary Retention in Spinal Subarachnoid Hemorrhage: An Experimental Study. World Neurosurg 2016;89:208-14.

5. Ozturk C, Kanat A, Aydin MD, Yolas C, Kabalar ME, Gundogdu B, et al. The impact of L5 dorsal root ganglion degeneration and Adamkiewicz artery vasospasm on descending colon dilatation following spinal subarachnoid hemorrhage: An experimental study; first report. J Craniovertebr Junction Spine 6:69-75, 2015

6. Gabella G, Davis C. Distribution of afferent axons in the bladder of rats. J Neurocytol 1998;27:141-55.

7. Aydin MD, Yildirim OS, Gundogdu C, et al. Thrombogenetic effect of facet denervation using in disc surgery on spinal radicular arteries: an experimental study. Minim Invasive Neurosurg 2006;49:328-30.

8. Aydin MD, Dane S, Gundogdu C, et al. Neurodegenerative effects of monopolar electrocauterization on spinal ganglia in lumbar disc surgery. Acta Neurochir (Wien)2004;146:1125-9; discussion 9.

9. Bayram E, Çalik M, Atalay C, et al. Destructive effect of monopolar electrocautery knife usage on femoral artery endothelium during spine surgery: experimental study. Eurasian J Med 2009;41:91-4.

10. Kenton K, Simmons J, FitzGerald MP, et al. Urethral and bladder current perception thresholds: normative data in women. J Urol 2007;178:189-92; discussion 92.

11. Andersson KE. Bladder activation: afferent mechanisms. Urology 2002;59:43-50.

12. Leedy M, Beattie M, Bresnahan J. Testosterone-induced plasticity of synaptic inputs to adult mammalian motoneurons. Brain research 1987;424:386-90. 